\title{
MIR9-3 Pre-miRNA
}

National Cancer Institute

\section{Source}

National Cancer Institute. MIR9-3 Pre-miRNA. NCI Thesaurus. Code C82738.

MIR9-3 pre-miRNA is an oligoribonucleotide that is encoded by the human MIR9-3 gene and is involved in the regulation of gene expression. 